\title{
The Influence of University Entrance Examination Results, Gender and Field of Study on Semester Cumulative Grade-point Averages (CGPAs) of First Year Students: The Case of Raya University
}

\author{
Mengesha Nigus Birhanu \\ College of social science and Humanities, Raya University, Po Box 92, Maychew, Ethiopia
}

\begin{abstract}
The purpose of this study was to assess the influence of university entrance examination results, gender and field of study on semester CGPA score of freshman students. A descriptive research design was employed for the present study. For the study 200 participants (119 males and 81 females) were selected through stratified random sampling technique. The data were gathered mainly from secondary sources found in the registrar office of Raya University. Descriptive statistics, Spearman correlation, multiple regression and Independent samples T-tests were applied to analyze the data. Sex of students $(0=$ female and $1=$ male) had a statistically significant relationship with semester CGPA scores; university entrance exam results and field of study revealed very weak positive and statistically non-significant relationship with semester CGPA scores. Multiple regression model selected sex and university entrance examination results as statistically significant predictors of semester CGPA scores and field of study was not statistically significant predictor, but only sex was statistically significant contributor in their relative contribution to students' CGPA scores. Independent samples t-test revealed a statistically sex differences on semester CGPA scores of students (favoring males). Further research with advanced approaches was recommended for other investigators on students CGPA scores and their influencing factors.
\end{abstract}

DOI: $10.7176 / \mathrm{JEP} / 10-25-02$

Publication date:September $30^{\text {th }} 2019$

\section{Chapter One}

Introduction

\subsection{Background of the Study}

In the present era of globalization and technological revolution, education is considered as a first step for every human activity. It plays a vital role in the development of human capital and is linked with an individual's wellbeing and opportunities for better living (Battle \& Lewis, 2002cited in Farooq, Chaudhry, Shafiq, Berhanu, 2011). It ensures the acquisition of knowledge and skills that enable individuals to increase their productivity and improve their quality of life. Educators, trainers, and researchers have long been interested in exploring variables contributing effectively for quality of performance of learners (Farooq, Chaudhry, Shafiq, Berhanu, 2011).

Students in many countries are expected to sit for national examination to join their academic institution. However, the type of assessment or entrance examination varies from nation to nation. Some institutions administer certain types of well-established globally recognized examinations. For instance most of the US colleges and universities require that all their applicants take one or more standardized tests such as SAT (Scholastic Aptitude Test), GRE (Graduate Record Examination), GMAT (Graduate Management Admission Test) and TOEFl (Test of English as a foreign language), while others administer locally-developed examinations to screen students for pursuing their academic career (Atkinson, 2001).

It is a common practice that different institutions depend on previous achievements to predict the success of students in their upcoming performance. As per to MOE (2002) cited in Desta, 2017, a national examination is one of the assessments that Ethiopian education system uses to identify competent and academically fit students for higher education programs. It is assumed that competition through national examination can raise quality of education in the higher institution. Thus, prior to getting the chance for college entrance examination, student teachers are allowed to compete using their Ethiopian General Secondary Education Certificate Examination result and high school transcript record average score. The higher their score in such two assessment results, the higher the probability to sit for college entrance examination (Desta ,2017).

In the past, the notion of gender gaps in higher education has been viewed from the perspective of inequities faced by females as they progress through the educational pipeline. Even today, the topic of gender differences continues to receive significant attention at both the institutional and national levels. Although the number and performance of female college students has substantially increased, a gender gap still exists, causing some researchers to examine this gap during the college years (Musise, Kathryn and Christopher, 2012).

Furthermore students' academic performance or CGPA scores has been be influenced by their field of study or specialization they joined. University students' academic achievement or CGPA scores shown a variation across different field of studies, studies conducted from college level and department wise inquiries (Gbeze, 2017). 
The ESLCE had long been the single requirement that high school graduates had to pass and join higher learning institution until the country made a reform on its education system Ethiopian. In 1994 E.C, the Transitional Government of Ethiopia formulated and implemented a new Education and Training Policy (MoE, 1994 cited in Yoseph, 2014) and ESLCE was replaced by other examinations on the basis of the new curriculum designed by the Ministry of Education (MoE). According to this policy, national examinations would be administered at grades 10 and 12. These examinations are known as the Ethiopian General Secondary Education Certificate Examination (EGSECE) and University Entrance Examination (UEE). The EGSECE is administered at the completion of grade10 while UEE is administered at the completion of grade twelve (Yoseph, 2014).

There is a relatively large body of research on the prediction of college GPA. These groups of factors might be emanated from internal and/or external factors. Aboma (2008) identified two types of predictors of college or university GPA: Cognitive or ability (traditional measures) and non-cognitive or affective (non-academic) factors. Cognitive factors generally refer to measures such as high school grades and standardized test scores (e.g., the Standardized Aptitude Test (SAT) and the American College Testing [ACT]). And non-cognitive measures are related to psychological factors, like social support and academic related skills. Some researchers showed the importance of traditional predictors for academic success (Noble, 1991; Reason, Terenzini \& Domingo, 2006 cited in Aboma, 2008). Others stressed on non-cognitive factors to sufficiently predict which students will succeed or fail in university (Tracey \& Sedlacek, 1984; White \& Sedlacek, 1986 cited in Aboma, 2008).

However there are different factors that might influence students' academic success or CGPA at college or university level this study emphasizes on the influence of university entrance exam results, gender and field of study on semester CGPA of Raya University students.

\subsection{Statement of the Problem}

The first year in university is a critical transition period. This is because it is a time when students lay the foundation on which their subsequent academic success and persistence rest. A bulk of literature on the prediction of academic success and retention among first year university students showed that most students, despite of the academic, social, emotional, and other challenges, successfully complete the transition period and achieve academic success (e.g., DeBerad, Julka \& Spielmans, 2004 cited in Olani, 2008).

The Ethiopian Ministry of Education, which is responsible for the award of certificates and placement of students in the universities, has been facing a lot of criticisms due to the fact that university graduates have poor quality. Several professionals and researchers in education have claimed that the magnificent days of high academic performance and enviable achievement among Ethiopian undergraduates have reached a vanishing point.

University life is considered as very challenging to every student academically. Furthermore, having successful results is a dream for every student since university is the last institution before they face the working life. That is why there is a need for research particularly to identify important factors that is related with psychological and academic performance of the students Khan, M. (2013), Mazlan, I., \& Hajar, J. (2016) Bandura, A. (1997) cited in Mazlan, Fadhirul, Mohamed, Mohdl and Ahmad (2017).

Various studies have been conducted on different factors that can affect students' academic achievement at university level at the international and national level professional investigations. For example, Similarly, Mazlan, Fadhirul, Mohamed, Mohdl and Ahmad (2017) found statistically significant positive relationship between gender and CGPA scores of students, favoring males on their GPA scores. On the other hand, Cumhur and Ismail (2007) conducted in Turkey; found that female students get higher CGPA than male students. While studies conducted in different countries of Ethiopia, including Desta,

A study conducted by Desta (2017) concluded that the predictors of college performance depend on the program of study or field of study they joined. This agrees with the former research findings by Scott-Clayton (2012) and Melaku (2014), cited in (Desta 2017). According to Scott-Clayton (2012), the predictors of future success of students vary from program to program. Similarly; Melaku (2014) from a study conducted on different programs of study conducted in Addis Ababa University indicated that the predictive power of variables for the success of university first year achievement depend on the type of program of study.

However there are different studies regarding to CGPA scores of students with their predicting variables at international and national levels, there was no a previous study in the intended study area since the university is newly emerged. Nowadays, cheating during the entrance examination sessions is coming to be the headache of ministry of education, which might influence the reliability of students' performance. With the consideration of entrance examination results and gender, students are assigned to different field of studies, which might influence their future success. Besides, the dynamic nature of different systems of the world and the nation requires updated information regarding to factors influencing students' academic success at university level. On the other hand Raya University, where the study was conducted, is a newly emerged and consisted of only first year students during the academic year of 2017/18. Because of this the number of departments and colleges were very limited; and students who assigned to the university have relatively low entrance exam results, comparing to senior universities. Considering these situations, this study was intended to investigate the influence of university entrance 
examination results, field study and gender on students' semester CGPA scores to fill the gap.

In general this paper was intended to answer the following research questions.

1. Is there a significant relationship between the predictor variables (university entrance examination, gender and field of study) and students' semester GPAs?

2. Which predictor variable is the most determinant to students' semester CGPA?

3. Is there a statistically significant gender difference on semester CGPA scores of first year students?

\subsection{Objectives of the study}

The purpose of this study was to investigate university entrance examination, sex and field of study as predictors of first year students' GPA among Raya University students.

\subsubsection{Specific Objectives}

The specific objectives of the study include:

- To examine the interrelationship between predictor variables (university entrance examination, sex and field of study) and semester CGPAs of students.

- To see gender differences among first year students' GPA scores.

- To identify the most predictor variable among predictor variables of the study?

\subsection{Significance of the Study}

Studying predicting variables of students' academic scores can contribute to the qualitative development of the community and the nation at large for a short and long term level. Specifically, investigating academic outcomes of students in relation to predictor variables can have a significant enhancement in the quality of education. In sum, the study would have the following significances:

$\$$ Increase awareness among different stakeholders like Ministry of Education and professionals like psychologists, sociologists and educators about the predicting variables to students GPA scores at university or college levels.

$\$$ Elicit insights for enhancing students' academic outcomes with better identification of variables that may predict their academic success.

\$ Serving as a literature support and source of information for more understanding of students' academic scores vis-à-vis predictor variables.

\$ Motivating other researchers to conduct further research and investigation on the issue of predictor variables to students GPA scores.

\subsection{Operational Definitions}

1. Field of study: in this study field of study was the college students joined in the university.

2. Gender: in this study gender refers to being male or female students included in the study.

3. Semester cumulative Grade point average (CGPA): the average grade result of students takes throughout the semester.

4. University entrance exam results: refers to the examination result held by ministry of education after students complete grade twelve or preparatory level.

\section{Methodology}

\subsection{Study Design}

The main purpose of the study was to investigate the prediction power of university entrance examination result, sex and field of study to CGPA scores of first year students in Raya University. Thus, descriptive research design was employed because it was intended to describe the existing relationship between variables. To this end, the study was mainly correlational in nature.

\subsection{Study Area}

The study was conducted among first year students of Raya University, which is found in Maichew, Ethiopa. The study site was selected based its familiarity and accessibility.

\subsection{Population and Sampling Frame}

The population of the study included first year students in Raya University, which consisted of a total number of 1347 (with 799 male and 548 female) students who completed and taken first semester final exam in 2017/18 academic year. Out of this number, the College of Agriculture and Environmental Science accounts 194 (male 102 and female 92) students; Business and Economics 446 (male 295 and female 151) students; Engineering and Technology 329 (male 241 and female 66) students; Natural and Computational Science 235 (male 98 and female 137) students; and Social Science and Humanities 143 (male 63 and female 80) students. The target population for the main study was regular freshman students of Raya University. Those freshman students were targeted as those would serve an appropriate source for study. Therefore, this would be important to see the importance of the issue 
from those participants with different field of study and groups. According to Creasey (2000) cited in Misaye (2009), sampling participants from different levels or backgrounds represent a powerful way to enhance external validity or generalizability of a study.

\subsection{Sample Size and Sampling Techniques}

According to the registrar office of Raya University, there were 5 colleges and 17 departments 1347 students who have taken first semester final exam. Stratified random sampling was employed to select sample participants of the study. Participants were proportionally selected as participant groups with total sample of 200 (119 male and 81 female) students. In order to select the participants, first the University was stratified based on sex and college levels and then, 29(male 15 and female 14) students from Agriculture and Environmental Science; 66(male 43 and female 23) students from Business and Economics; from Engineering and Technology 49(39 male and 10 female) students; from Natural and Computational Science 35(male 14 and female 21) students; and 21(male 8 and female 13) students from Social Science and Humanities were randomly selected. The sample size was determined by using Curry's (1984) assumption with the "rule of thumb", $10 \%$ of large populations and 20\% of small populations as minimums (Yount, 2006).

\subsection{Tools of Data Collection}

The main variables of the study were university entrance examination result, sex and field of study as independent variables and semester GPA scores as dependent variable. The data were collected using a secondary data and the necessary information was taken from the registrar office of the university.

\subsection{Procedures}

\subsubsection{Administration and Scoring}

The data were administered from registrar office semester results in line with their college or faculty based category. After the random selection of participants from their stratum, their university entrance examination result, sex and semester GPA scores were recorded. Then after, the collected data were scored accordingly for the statistical analysis.

\subsubsection{Data Analysis}

The data were analyzed by using the SPSS/PC computer statistical package version 20. To describe the demographic characteristics of participants, descriptive statistics were employed. A Spearman correlation was employed to investigate the relationship between independent variables (university entrance exam, sex and field of study) and the dependent variable (GPA scores) of students. Stepwise multiple regressions have been employed to see the most predictor of students' GPA scores. Besides, an independent t-test was used to indicate gender differences on GPA scores of

\subsection{Ethical Considerations}

The study was received ethical approval from Academic and research vice president of Raya University. Acceptance of the registrar officials was assured to conduct the study. In addition, verbal consent with responsible bodies was obtained after being fully informed of the study purpose and procedures. Confidentiality and anonymity was ensured.

\section{Results}

This chapter is concerned with the presentation, analysis and interpretation of data in line with the categories of the research prepared. As it was already explained in the purpose of the study, the study was launched to investigate the prediction of university entrance exam, sex and field of study to students GPA scores among Raya university freshman students. The collected data were categorically analyzed and inferences were made in relation to the basic research questions.

\subsection{Demographic Characteristics of Respondents}

\subsubsection{Sex of Students}

The sex distribution of participants students were 119(59\%) male and 81(41\%) female participants. This corresponds with relatively greater sex ratio of male students in the population. 


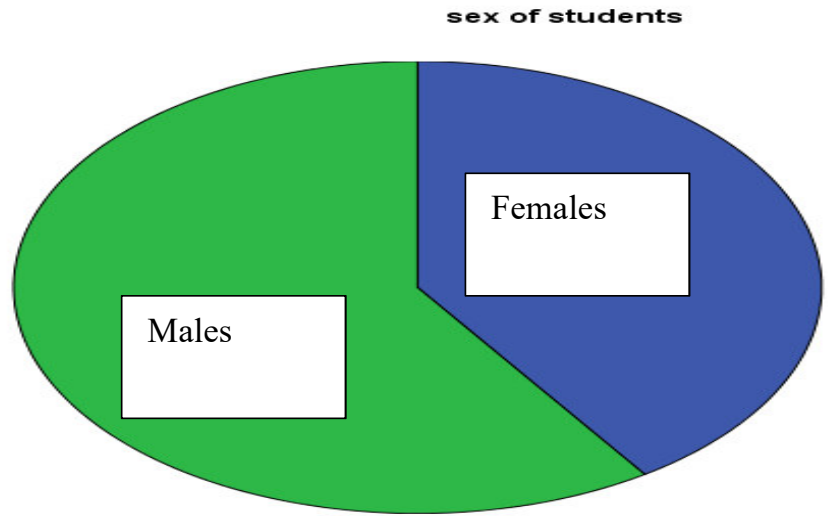

3.1.2. Field of Study of Participants

Table 1: Participants' field of study

\begin{tabular}{|c|l|c|c|}
\hline No. & \multicolumn{1}{|c|}{ College } & Frequency & Percent \\
\hline 1. & College of agriculture and Environmental Science & 29 & 14.5 \\
\hline 2. & College of business and economics & 66 & 33.0 \\
\hline 3. & College of engineering and technology & 49 & 24.5 \\
\hline 4. & College of natural and computational science & 35 & 17.5 \\
\hline 5. & College of social science and humanities & 21 & 10.5 \\
\hline 6. & Total & 200 & 100.0 \\
\hline
\end{tabular}

Regarding to type of study participants joined, the above Table 1 shown that $21(10.5 \%)$ were from college of social science and humanities; 66 (33\%) were from college of business and economics; $29(14.5 \%)$ from college of agriculture; College of agriculture and Environmental Science 29(14.5\%); College of natural and computational science $35(17.5 \%)$ and the remaining $49(24.5 \%)$ were from College of engineering and technology. The college distribution of respondents was based on the proportional distribution students from all colleges.

\subsubsection{Mean Scores of Students' University Entrance Exam and Semester CGPA}

As clearly shown in Table 2 below, there was a total mean score of 383.74 on university entrance exam results of students with minimum score of 335 and maximum of 489. The inter college comparison of mean scores on university entrance examination results higher was revealed in college of agriculture and environmental science $(\mathrm{M}=414.62$; $\mathrm{Max}=489 ; \mathrm{Min}=380 ; \mathrm{R}=109$ and $\mathrm{SD}=31.27)$ followed by College of engineering and technology $(\mathrm{M}=399.10 ; \mathrm{Max}=465 ; \mathrm{Min}=371 ; \mathrm{R}=94$ and $\mathrm{SD}=27.29)$ and College of business and economics $(\mathrm{M}=386.26$; $\mathrm{Max}=458$; $\mathrm{Min}=368 ; \mathrm{R}=90$ and $\mathrm{SD}=18.86)$. On the other hand the least mean score on university entrance examination result was observed in College of natural and computational science $(\mathrm{M}=350.71$; $\mathrm{Max}=359$; $\mathrm{Min}=335$; $\mathrm{R}=52$ and $\mathrm{SD}=14.68)$ and followed by College of social science and humanities $(\mathrm{M}=352.38$; $\mathrm{Max}=387$; Min=344; $\mathrm{R}=15$ and $\mathrm{SD}=4.63$ ).

Regarding to semester CGPA scores of students, there was a total mean score of 2.4 with minimum result of 0.6 and maximum of 4.00. The mean score of semester CGPA score across the five colleges was somewhat high in College of social science and humanities $(\mathrm{M}=2.56$; $\mathrm{Max}=3.83$; $\mathrm{Min}=1.13 ; \mathrm{R}=2.70$ and $\mathrm{SD}=.71)$, followed by College of engineering and technology and College of business and economics $(\mathrm{M}=2.54$; $\mathrm{Max}=4.00$; Min=1.08; $\mathrm{R}=2.92$; and $\mathrm{SD}=.82$ and $\mathrm{M}=2.48 ; \mathrm{Max}=3.96 ; \mathrm{Min}=.60 ; \mathrm{R}=3.36$ and $\mathrm{SD}=.83)$ respectively. The least mean score of students' semester CGPA was observed in College of agriculture and environmental science $(\mathrm{M}=2.02$; $\mathrm{Max}=4.00 ; \mathrm{Min}=1.05 ; \mathrm{R}=2.95$ and $\mathrm{SD}=.55$ ) and followed by College of natural and computational science $(\mathrm{M}=2.29 ; \operatorname{Max}=3.88 ; \mathrm{Min}=.64 ; \mathrm{R}=3.24$ and $\mathrm{SD}=.98)$.

This result indicated slightly greater range differences of total grand scores on both university entrance exam results and semester CGP scores of students with a range score of 154 and 3.4 respectively. Whereas the inter college comparisons indicated higher range difference of university entrance exam results in collage of agriculture and environmental science $(\mathrm{R}=109)$; followed by College of engineering and technology and College of business and economics $(\mathrm{R}=94$ and $\mathrm{R}=90$ respectively). Whereas the least range score was observed in college of social science and humanities $(\mathrm{R}=15)$ and followed by college of natural and computational science $(\mathrm{R}=52)$. 
Table 2: Students' mean score on university entrance exam results and semester CGPA (N=200)

\begin{tabular}{|c|c|c|c|c|c|c|c|}
\hline No. & Variables & Items & Min & Max & Mean & Range & SD \\
\hline \multirow[t]{6}{*}{1.} & \multirow{6}{*}{$\begin{array}{l}\text { University } \\
\text { entrance } \\
\text { examination } \\
\text { results of } \\
\text { students }\end{array}$} & $\begin{array}{l}\text { College of agriculture and Environmental } \\
\text { Science }\end{array}$ & 380 & 489 & 414.62 & 109 & 31.27 \\
\hline & & College of business and economics & 368 & 458 & 386.26 & 90 & 18.86 \\
\hline & & College of engineering and technology & 371 & 465 & 399.10 & 94 & 27.29 \\
\hline & & $\begin{array}{l}\text { College of natural and computational } \\
\text { science }\end{array}$ & 335 & 387 & 350.71 & 52 & 14.68 \\
\hline & & College of social science and humanities & 344 & 359 & 352.38 & 15 & 4.63 \\
\hline & & Grand total scores & 335 & 489 & 383.74 & 154 & 31.1 \\
\hline \multirow[t]{6}{*}{2.} & \multirow{6}{*}{$\begin{array}{l}\text { Semester } \\
\text { CGPA of } \\
\text { students }\end{array}$} & $\begin{array}{l}\text { College of agriculture and Environmental } \\
\text { Science }\end{array}$ & 1.05 & 4.00 & 2.02 & 2.95 & 0.55 \\
\hline & & College of business and economics & 0.60 & 3.96 & 2.48 & 3.36 & 0.83 \\
\hline & & College of engineering and technology & 1.08 & 4.00 & 2.54 & 2.92 & 0.82 \\
\hline & & $\begin{array}{l}\text { College of natural and computational } \\
\text { science }\end{array}$ & 0.64 & 3.88 & 2.29 & 3.24 & 0.98 \\
\hline & & College of social science and humanities & 1.13 & 3.83 & 2.56 & 2.70 & 0.71 \\
\hline & & Grand total scores & 0.6 & 4.00 & 2.4 & 3.40 & 0.82 \\
\hline
\end{tabular}

Regarding to semester CGPA scores, the higher range difference was observed in College of business and economics $(\mathrm{R}=3.36)$; followed by college of natural and computational science $(\mathrm{R}=3.24)$ and college of agriculture and environmental science $(\mathrm{R}=2.95)$. On the other hand, the least range difference has been observed in college of social science and college of engineering and technology $(\mathrm{R}=2.70$ and $\mathrm{R}=2.92$ respectively).

\subsection{The Inter-correlation between Predictor Variables (Field of study, gender and university entrance exam results and the outcome Variable (semester CGPA)}

The basic question of the study was to see the relationship between predictor variables and outcome variable (semester CGPA) of first year students. For that reason, Spearman correlation was used to see their relationship.

As depicted in Table 3 below, sex of students $(0=$ female and $1=$ male $)$ had a statistically significant relationship with the predictor variable of university entrance exam results $(\mathrm{rx} 1 \times 3=0.283, \mathrm{p}<0.01)$ and the predicted variable of semester CGPA scores ( $\mathrm{rx} 1 \mathrm{y} 1=0.236, \mathrm{p}<0.01)$; and it was negatively related but statistically non-significant with field of study ( $\mathrm{r} \times 1 \times 2=-0.105, \mathrm{p}>0.05)$. This indicates that as students become male, the university entrance exam results and semester CGPA scores of students increase.

On the other hand field of study has shown negative and statistically significant relationship with university entrance exam results ( $\mathrm{rx} 2 \times 3=-0.641, \mathrm{p}<0.01)$, but very weak positive and statistically non-significant relationship was shown with semester CGPA scores $(\mathrm{rx} 2 \mathrm{y} 1=0.120, \mathrm{p}>0.05)$. This result implies that university entrance exam results shown a decrement when we move to the ascending order of the codes given to the field of studies i.e. the results are lower across social science and humanities as well as natural and computational science colleges, but relatively higher across the rest colleges.

Table 3: The Inter-correlation matrix between Predictor variables and Outcome Variable

\begin{tabular}{|l|l|l|l|l|}
\hline Variables & $\mathrm{X} 1$ & $\mathrm{X} 2$ & $\mathrm{X} 3$ & $\mathrm{Y} 1$ \\
\hline Sex (x1) & 1 & & & \\
\hline Field of Study (college) (x2) & -0.105 & 1 & & \\
\hline University entrance exam results (x3) & $0.283^{* *}$ & $0.641^{* *}$ & 1 & \\
\hline Semester CGPA scores (y) & $0.236^{* *}$ & 0.120 & 0.092 & 1 \\
\hline
\end{tabular}

$* * \mathrm{p}<0.01 \quad \mathrm{~N}=200$

Finally, university entrance exam results revealed very weak and statistically non-significant relationship with semester CGPA result of students ( $\mathrm{rx} 3 \mathrm{y} 1=0.092, \mathrm{p}>0.05)$.

\subsubsection{The Strength of Overall Relationship between Sex of students, Field of study and university entrance exam and Semester CGPA}

The analysis below presents the regression analysis of the predictive power of predictor variables. Stepwise multiple regression method was chosen to analyze the relationship between the criterion and predictor variables as this method essentially decides which independent variable is the best predictor, the second best predictor and so on until all the variables that significantly predict the criterion variable exhausted. 
Table 4: Multiple correlation coefficients and percentage of variances explained by sex, field of study and university entrance exam results to semester CGPA

\begin{tabular}{|c|c|c|c|c|c|c|c|c|}
\hline Predictors & $\mathbf{R}$ & $\mathbf{R}^{2}$ & Adjusted $\mathbf{R}^{2}$ & Se & $\triangle \mathbf{R}^{2}$ & $\triangle \mathbf{F}$ & Df1 & Df2 \\
\hline Sex of respondents & .246 & .061 & .056 & .79832 & $.061 * *$ & 12.779 & 1 & 198 \\
\hline Field of study of students & .279 & 078 & .068 & .79298 & .017 & 3.677 & 1 & 197 \\
\hline University entrance exam results & .315 & .099 & .085 & .78575 & $.021 \%$ & 4.640 & 1 & 196 \\
\hline
\end{tabular}

\section{$* * p<0.01 * p<0.05 \quad S e=$ standard error, $\triangle R^{2}=$ change in $R \quad \triangle F=$ change in $F$}

Table 4 shows that in stepwise multiple regression, which considers the predictor variables individually, it was found that sex of students accounted $6.1 \%$ additional variance explained in semester CGPA; and this increment in coefficient of determination was significant $[\triangle F(1,198)=12.779, p<0.01]$. The second predictor variable, field of study accounted $1.7 \%$ additional variance in semester CGPA score of first year students, this increment in coefficient determination was not statistically significant $[\triangle F(1,197)=3.677, p>0.05]$. The addition of field of study in the second model increased the variance accounted for by the combination of the two steps in semester CGPA to $\left(\mathrm{R}^{2}=0.078\right) 7.8 \%$. Finally, the third predictor variable, university entrance exam results accounted additional variance of $2.1 \%$ in semester CGPA score of first year students; and its increment in coefficient of determination was found to be statistically significant $[\triangle F(1,196)=4.640, p<0.05]$. The addition of university entrance exam results in the third model increased the variance accounted for by the combination of the three steps in semester CGPA to $\left(\mathrm{R}^{2}=0.099\right) 9.9 \%$.

Table 5: Summary of one way analysis of variance for the multiple regression analysis

\begin{tabular}{|c|c|c|c|c|c|}
\hline Variables entered & $\begin{array}{c}\text { Sources } \\
\text { variance }\end{array}$ & $\begin{array}{c}\text { Sum of } \\
\text { Squares }\end{array}$ & df & $\begin{array}{l}\text { Mean } \\
\text { Square }\end{array}$ & $\mathbf{F}$ \\
\hline \multirow[t]{3}{*}{ Sex of students } & Regression & 8.144 & 1 & 8.144 & $12.779 * *$ \\
\hline & Residual & 126.188 & 198 & .637 & \\
\hline & Total & 134.332 & 199 & & \\
\hline \multirow{3}{*}{$\begin{array}{l}\text { Sex of students and Field of study of } \\
\text { students }\end{array}$} & Regression & 10.456 & 2 & 5.228 & $8.314 * *$ \\
\hline & Residual & 123.876 & 197 & .629 & \\
\hline & Total & 134.332 & 199 & & \\
\hline \multirow{3}{*}{$\begin{array}{l}\text { Sex of students, Field of study of } \\
\text { students and University entrance } \\
\text { exam results }\end{array}$} & Regression & 13.321 & 3 & 4.440 & $7.192 * *$ \\
\hline & Residual & 121.011 & 196 & .617 & \\
\hline & Total & 134.332 & 199 & & \\
\hline
\end{tabular}

$* * \mathbf{p}<\mathbf{0 . 0 1} * \mathbf{p}<\mathbf{0 . 0 5}$

As can be observed from Table 5, in the first step, the stepwise regression entered sex of students and it explained significantly the first year semester CGPA $\left(\mathrm{F}_{1,198}=12.779, \mathrm{p}<0.01\right)$. In the second step the model entered sex of students and Field of study where the addition of Field of study was found to be significant predictor of first year CGPA $\left(\mathrm{F}_{2,197}=8.314, \mathrm{p}<0.01\right)$. At the third step of the stepwise regression three variables: sex of students, Field of study and University entrance exam results were selected and entered where the further addition of the third variable significantly predicted first year CGPA $\left(\mathrm{F}_{3,196}=7.192, \mathrm{p}<0.01\right)$.

Table 6: Relative contribution of predictor variables to the semester CGPA of students

\begin{tabular}{|c|c|c|c|c|c|c|}
\hline Predictor Variables & Constant & B & Std. Error & $\beta$ & $\mathbf{t}$ & Sig \\
\hline Sex of respondents & 2.16 & .41 & 0.12 & 0.246 & $3.575 * *$ & .000 \\
\hline Sex of respondents & \multirow{2}{*}{1.98} & .44 & 0.12 & 0.263 & $3.814^{* *}$ & .000 \\
\hline Field of study & & .090 & 0.05 & 0.132 & 1.918 & .057 \\
\hline Sex of respondents & \multirow{3}{*}{.01} & 0.39 & 0.12 & 0.235 & $3.374 * *$ & .001 \\
\hline Field of study & & 0.16 & 0.06 & 0.238 & $2.829 * *$ & .005 \\
\hline University entrance exam result & & 0.01 & 0.00 & 0.185 & $2.154 *$ & .032 \\
\hline
\end{tabular}

$* \mathbf{P}<0.05, * * \mathbf{p}<0.01$

In Table 6, "B" stands for the unstandardized coefficients of regression and " $\beta$ " stands for the standardized coefficients of regression. The regression model when sex of students was used as the predictor by excluding the other predictors was $\bar{Y}=2.16+0.41 \mathrm{X}_{1}$ where $\mathrm{X}_{1}$ is sex of students. The coefficient of regression for this model was significant $(\beta=0.246, t=3.575, p<0.01)$. The combination of sex of students and the Field of study by the stepwise regression produced the prediction model of $\bar{Y}=1.98+0.44 \mathrm{X}_{1}+0.090 \mathrm{X}_{2}$, where $\mathrm{X}_{2}$ is field of study. The coefficient of regression for this model was significant only to sex of respondents $(\beta=0.263, t=3.814, p<0.01)$. Likewise at the third step, the stepwise regression produced a model for predicting first year semester CGPA by the combination of three predictor variables with a prediction model of $\bar{Y}=0.01+0.39 \mathrm{X}_{1}+0.16 \mathrm{X}_{2}+0.01 \mathrm{X}_{3}$, where $\mathrm{X}_{3}$ is the university entrance exam result. The regression coefficients for this model were significant $(\beta=0.235, \mathrm{t}=3.374, \mathrm{p}<0.01 ; \beta=0.238, \mathrm{t}=2.829, \mathrm{p}<0.01 ;$ and $\beta=0.185, \mathrm{t}=2.154, \mathrm{p}<0.05$ respectively $)$. 


\subsection{Gender Differences in Semester CGPA of Students}

In order to examine sex differences of students on their semester CGPA scores, an independent t-test statistical analysis has been employed.

Table 7a Group statistics

\begin{tabular}{|c|c|c|c|c|c|}
\hline & Sex of students & $\mathrm{N}$ & Mean & Std. Deviation & Std. Error Mean \\
\hline \multirow{2}{*}{ Semester CGPA of students } & Female & 81 & 2.1593 & .75767 & .08419 \\
\cline { 2 - 6 } & Male & 119 & 2.5703 & .82474 & .07560 \\
\hline
\end{tabular}

Table 7b Independent Samples Test

\begin{tabular}{|c|c|c|c|c|c|c|c|c|c|c|}
\hline & \multicolumn{2}{|c|}{$\begin{array}{l}\text { Levene's Test } \\
\text { for Equality of } \\
\text { Variances }\end{array}$} & \multicolumn{7}{|c|}{ t-test for Equality of Means } \\
\hline & & \multirow[t]{2}{*}{$\mathrm{F}$} & \multirow[t]{2}{*}{ Sig. } & \multirow[t]{2}{*}{$\mathrm{t}$} & \multirow[t]{2}{*}{$\mathrm{df}$} & \multirow[t]{2}{*}{$\begin{array}{l}\text { Sig. } \\
(2- \\
\text { tailed) }\end{array}$} & \multirow[t]{2}{*}{$\begin{array}{c}\text { Mean } \\
\text { Difference }\end{array}$} & \multirow[t]{2}{*}{$\begin{array}{l}\text { Std. Error } \\
\text { Difference }\end{array}$} & \multicolumn{2}{|c|}{$\begin{array}{l}95 \% \text { Confidence } \\
\text { Interval of the } \\
\text { Difference }\end{array}$} \\
\hline & & & & & & & & & Lower & Upper \\
\hline \multirow{2}{*}{$\begin{array}{l}\text { Semester } \\
\text { CGPA } \\
\text { of } \\
\text { students }\end{array}$} & $\begin{array}{c}\text { Equal } \\
\text { variances } \\
\text { assumed }\end{array}$ & 1.948 & .164 & -.575 & 198 & .000 & -.41108 & .11499 & -.63785 & -.18431 \\
\hline & \begin{tabular}{|c} 
Equal \\
variances \\
not \\
assumed
\end{tabular} & & & -3.633 & 181.181 & .000 & -.41108 & .11315 & -.63434 & -.18781 \\
\hline
\end{tabular}

As depicted in the above Table 7a male participants had slightly greater mean scores $(\mathrm{M}=2.5703, \mathrm{SD}=.82474)$ than that of female participants $(M=2.1593, S D=.75767)$ on their semester CGPA. Likewise the above Table $7 \mathrm{~b}$ shown that there was a statistically significant difference between male and female students $(\mathrm{t}=-0.575, \mathrm{p}<0.01)$, favoring males, on their semester CGPA. For this analysis, Equal variances assumed or the variances for the two groups (males/females) are not the same was considered. Because, Levene's Test for Equality of Variances significance level was found as, $\mathrm{p}>0.05$.

\section{DISCUSSION}

The purpose of this study was to examine the influence of university entrance exam, gender and field of study on semester CGA scores of students. This part of the paper presents the discussion of the research findings based on the basic research questions raised at the beginning of the paper and in comparison with previous research findings and theories.

\subsection{The Relationship between University Entrance Exam Results, Field of Study and Gender and Semester CGPAs Score of Students}

The Spearman correlation matrix revealed that sex of students had a statistically significant relationship with semester CGPA scores ( $\mathrm{rx} 1 \mathrm{y} 1=0.236, \mathrm{p}<0.01)$. This indicates that as students become male, the university entrance exam results CGPA score of students increase. The current finding was similar with Gobeze (2017), who found statistically significant relationship between sex and GPA scores of students. Similarly, Mazlan, Fadhirul, Mohamed, Mohdl and Ahmad (2017) found statistically significant positive relationship between gender and CGPA scores of students. On the other hand field of study has shown statistically non-significant and very weak relationship with semester CGPA scores ( $\mathrm{rx} 2 \mathrm{y} 1=0.120, \mathrm{p}>0.05)$. This result implies that semester CGPA shown a decrement when we move to the ascending order of the codes given to the field of studies i.e. the results are lower across social science and humanities as well as natural and computational science colleges, but relatively higher through the rest colleges.

Finally, university entrance exam results revealed very weak and statistically non-significant relationship with semester CGPA result of students ( $\mathrm{rx} 3 \mathrm{y} 1=0.092, \mathrm{p}>0.05)$. This result was different from the finding by Yoseph $(2014 ; 2015)$, who discovered higher correlation coefficient between entrance exam result and freshman college CGPA, $\mathrm{r}=0.417, \mathrm{p}<0.01$.

Stepwise multiple regression found that sex of students was statistically significant determinant as the predictor to semester CGPA score $[\triangle F(1,198)=12.779, \mathrm{p}<0.01]$. This result was consistent with Gobeze's finding significant difference between male and female students college academic performance. But in the relative contribution predictor variables, it was not similar with Gobeze's finding, who found sex was not statistically significant in its relative contribution to semester CGPA. Whereas this study revealed that sex continued to be statistically significant contributor to students semester CGPA $(\beta=0.246, t=3.575, p<0.01)$. 
The second, statistically significant predictor variable to semester CGPA score, selected by stepwise multiple regression was university entrance exam results $[\triangle F(1,196)=4.640, p<0.05]$. The present result was similar with the findings of Aboma (2009), Desta (2017), Melaku's (2014) cited in Desta (2017), Gobeze (2017) and Yoseph $(2014 ; 2015)$

The third study variable, field of study was not found as statistically significant predictor to semester CGPA score. This result is different from the finding studied by Gobeze (2017), Scott- Clayton (2012) and Melaku (2014) cited in Desta (2017), who found field of study as statistically significant predictor to CGPA scores. This difference might be stemmed from the background of participants and the study have been taken from the newly emerged university, in which most of students assigned to the university had relatively lower than senior university students.

\subsection{Gender Differences on Semester CGPAs Score of Students}

Both the multiple regression and an independent samples T-test had shown a statistically significance difference between males and females in their overall scores of semester CGPA. In the regression model sex was the better statistically significant predictor of semester CGPA, which indicated being male led to well gained in semester CGPA scores.

An independent T-test result revealed that there was statistically significant difference on semester CGPA of first year students, with mean difference of -0.411 between male and female students mean scores of semester CPAs. This study was consistent with previous findings like Desta, 2017 and Gebeze, 2017) who found statistically significant sex difference on GPA scores.

\section{CONCLUSIONS}

Based on the major findings of the study, the following conclusions were made:

- Sex of students had a statistically significant relationship with semester CGPA scores and field of study has shown statistically non-significant and very weak relationship with semester CGPA scores. University entrance exam results revealed very weak and statistically non-significant relationship with semester CGPA result of students.

- Stepwise multiple regressions found that sex of students university entrance exam results were statistically significant determinant as the predictor to semester CGPA score and sex continued to be statistically significant contributor to students' semester CGPA in their relative contribution. And field of study was not found as statistically significant predictor to semester CGPA score.

- Statistically significance gender differences (favoring males) were drawn in students CGPA scores. Hence, it seems possible to conclude that males were more likely to be high achievers in their academic performance.

\section{RECOMMENDATIONS}

It would be important to recommend educators, parents, communities and other concerned bodies to help and facilitate students' academic scores at university level:

As long as the relationship between predictor variables and predicted variables is concerned, sex had shown statistically significant relationship with GPA scores of students. Since, it was found to be as students became males their academic achievement increases, there should be empowerment of females among the responsible bodies.

Sex and university entrance exam have been significant predictors of university academic success. Thus, those differences should be critically considered in academic achievement of university students.

Finally, this paper was conducted within only one university with limited number of participants and factors influencing students GPA score. Therefore, further research is recommended by other investigators for detail analysis of the issue.

\section{References}

Aboma.O. (2008). Predicting First Year University Students' Academic Success. Electronic Journal of Research in Educational Psychology, 7(3), 1053-1072.

Atkinson, R. H. (2001). Standardized tests and access to American universities: UC and the SAT. Speech available in the following web address: http://www.ucop.edu/ucophome/commserv/sat/speech.html.

Bachman, L. F., \& Palmer, A. (1996). Language testing in practice. Oxford: Oxford University Press.

Bridgeman, B., McCamley-Jenkins, L., \& Ervin, N. (2000).Predictions of freshman grade-point average from the revised and re-entered SAT I: Reasoning Test (College Board Research Report No. 2000-1). New York: The College Board.

Cleary, T. A. (1968). Test bias: Prediction of grades of Negro and White students in Integrated colleges. Journal of Educational Measurement, 5, 115-124.

Cronbach, L. J. (1951). Coefficient alpha and the internal structure of tests. Psychometrika, 16297-334.

Cronbach, L. J., Schoeneman, P., \& McKie, D. (1965). Alpha coefficients for stratified tests. Educational and 
Psychological Measurement, 25, 291-312.

Cumhur E. and Ismail S., (2007). Factors affecting Grade Point Average of university students https://www.researchgate.net/profile/

Elliott, R., \& Strentra, A. C. (1988). Effects of improving the reliability of the GPA on prediction generally and on comparative predictions for gender and race particularly. Journal of Educational Measurement, 25, 333347.

Farooq M.S., Chaudhry A.H, Shafiq M. and Berhanu G., (2011). Factors Affecting Students' Quality of Academic Performance: A Case of Secondary School Level Journal of Quality and Technology Management Vol- VII, Issue II, Dec., 2011, Page 01 - 14

Desta Gereme (2017). Assessing the Contribution of High School Achievements and College Entrance Examination on Pre-service Teachers' Performance; EURASIA Journal of Mathematics, Science and Technology Education, 2018, 14(5), 1803-1813 ISSN:1305-8223 (online) 1305-8215

Gobeze M (2017) Scholastic Aptitude Test, Sex and Department as Predictors of University Academic Performance: The Case of Addis Ababa University. Arts Social Sci J 8: 314. doi: 10.4172/21516200.1000314

Mazlan Ismail, Fadhirul Hisham Aziz, Mohamed Fajil A. B., Mohd Faiz Ismail, Ahmad Shah P. M., (2017). The Relationship between Self-Efficacy and GPA Grade Scores of Students, International Journal of Applied Psychology, Vol. 7 No. 2, 2017, pp. 44-47. doi: 10.5923/j.ijap.20170702.03.

Musise T., Kathryn R. and Christopher M., (2012). Effect of Gender on College Students' Satisfaction and Achievement: The Case of a Midsized Midwestern Public University: International Journal of Business and Social Science Vol. 3 No. 10 [S Issue - May 2012]

Yoseph S. R. (2015). University Entrance Exam Result and Preparatory Class Average Score as Predictors of College Performance, International Journal of Psychology and Behavioral Sciences, Vol. 1 N0.4, 2014, pp.103-113 | ISSN 2348-5396

Yoseph S. R. (2015). Determinants of Freshman CGPA: High School Result, Entrance Exam Result and EGSECE GPA, International Journal of Psychology and Behavioral Sciences, Vol. 5 No. 3, 2015, pp. 121-127. doi: 10.5923/j.ijpbs.20150503.03. 